\title{
Can matter and spirit be mediated through language? Some insights from Johann Georg Hamann
}

\author{
Author: \\ Detlev Tönsing ${ }^{1,2}$ \\ Affiliations: \\ ${ }^{1}$ School of Religion and \\ Theology, University \\ of KwaZulu-Natal, \\ Pietermaritzburg Campus, \\ South Africa \\ ${ }^{2}$ Lutheran Theological \\ Institute, University \\ of KwaZulu-Natal, \\ Pietermaritzburg Campus, \\ South Africa \\ Correspondence to: \\ Detlev Tönsing \\ Email: \\ tonsing@ukzn.ac.za \\ Postal address: \\ Private Bag X1, Scottsville \\ 3209, South Africa \\ Dates: \\ Received: 22 Oct. 2010 \\ Accepted: 03 Mar. 2011 \\ Published: 06 Feb. 2012 \\ How to cite this article: \\ Tönsing, D., 2012, 'Can \\ matter and spirit be \\ mediated through language? \\ Some insights from \\ Johann Georg Hamann', \\ HTS Teologiese Studies/ \\ Theological Studies 68(1), \\ Art. \#971, 5 pages. http:// \\ dx.doi.org/10.4102/hts. \\ v68i1.971
}

C) 2012. The Authors.

Licensee: AOSIS

OpenJournals. This work

is licensed under the

Creative Commons

Attribution License.
The Enlightenment introduced to European philosophy and thought-patterns the strict dichotomy between res extensa and res cogitans; that is, matter and spirit. How to overcome the dichotomy and conceive of the interactions between these planes of reality has since become an overarching issue for philosophers. The theory of evolution, as founded by Charles Darwin, understands human beings, with their ability to think, to have arisen in the evolutionary process. Neuroscience utilises insights from the theory of complex systems to attempt to understand how perception, thought and self-awareness can arise as a consequence of the complex system that is the brain. However, already at the height of the Enlightenment, a contemporary and critic of Immanuel Kant, Johann Georg Hamann, suggested a metaphor for understanding the interrelationship of matter and thought. This metaphor is language. The appropriateness of this metaphor can be seen both in the importance that language abilities play in the evolutionary transition to the human species and in the characteristics of complex adaptive systems.

\section{Introduction}

\section{Mind, matter, Calvin and Darwin}

In 2009, the second centennial of Darwin's birth, and the fifth of Calvin as theologian of the Holy Spirit, was celebrated. This conjunction can be used as an occasion to reflect on the relationship between spirit and the evolution of matter.

In this article, I will use the term 'spirit' in the sense of that which defines the human being and makes humans different from animals. This is in the sense of Genesis 2, where the breath of God makes the human being into what it essentially is. This passage, as well as the passage in Genesis 1 about the imago dei in humans, shows a link between the human spirit and the Spirit of God. At the end of this article, I will draw implications for what the concept of 'Spirit of God' may imply from my conclusions about the human spirit itself. The concept of the human spirit or soul has been widely and controversially discussed and I will not enter into discussions on the relationship between spirit and soul, their distinction, and whether one should distinguish between body and spirit or body, soul and spirit in humans. Instead, I will focus on the use of 'spirit' as that which defines humans as distinct from (other) animals.

Calvin (1843:171), as with Luther and medieval Catholicism, distinguishes the soul of the human being, which he acknowledges can also be termed 'spirit', from the body. It is this spirit that is the locus of the imago dei in humans and distinguishes humans from other beings. Examining the further distinctions of the soul - into intellect and will (Calvin 1843:180) - is beyond the scope of this article.

\section{Transcendental categories and language}

\section{Kant and Hamann}

In between the theories of Calvin and Darwin lie those of Descartes and Kant, representing the culmination of Enlightenment thought. The distinction between spirit and body, or matter, is developed further and entrenched as both Descartes and Kant separated the concept of spirit from matter - the res extensa from the res cogitans, the noumena from the phenomena.

Matter, with the main property of extension, is separated from intellect, which has the main ability of perception and thought. What is observed by the perceiving spirit is distinguished from the thing in itself. Kant reproduced the distinction between intellect and will within the spirit in his distinction between theoretical and practical reason in his two seminal works: Critique of pure reason (1781) and Critique of practical reason (1788). The division between spirit and matter was heightened to such an extent that one of the main difficulties of philosophy became how 
to explain the ability of human spirit to acquire information from the bodily senses and how the human spirit could effect instruction to the human body; that is, the mind-body problem (Carrier \& Mittelstrass 1995:16, 26).

The consequences of this separation are present with us today and can be seen in the issue of the observer in quantum mechanics. The wave function develops continuously and predictably in accordance with the Schrödinger equation - until there is an observation, at which point the wave function, which assigns probabilities to the outcomes of possible observations, collapses to the definite state of one definite observed answer. Which answer is observed is not predictable, but probabilistic. The wave function then resumes its continuous development - until the next observation. What exactly constitutes an observation, and what this implies for unobserved states, is still a topic of discussion in interpretations of quantum mechanics (Laurikainen 1991:198; Shimony 2001:5).

Another consequence of the mind-body dualism is the relative devaluation of the body, as opposed to the intellect prevalent in Western culture. This can be seen in the relative value attached to manual and intellectual labour, as well as in the valuation of objects primarily in terms of the specific human contribution to their existence (Smith 1843 [1776]:20). Yet, in this conception, because value is given only to the human input in production, this devalues those aspects of nature untouched by humans. If that which is not made by humans is conceived as valueless, such a conception can be argued to be a major contributor to environmental degradation. Mind-body, spirit-matter dualism is therefore arguably at the root of some of the most important issues of our time. So how can this dualism be overcome?

As a contemporary critic and friend of Immanuel Kant, Johann Georg Hamann may contribute to finding an approach to answering this question. Hamann assisted Kant in the publication of the Critique of pure reason. Having therefore had access to the text before publication, he wrote a response very soon after its appearance, although this was only published much later in respect for his friendship with Kant. He named this response Metakritik über den Purismus der Venunft (1825 [1784]), thereby coining the term 'metacritique'. He concludes this response, a mere 14 pages long in comparison with the 440 pages of the Kant's work, with the words:

This last possibility to draw the form of an empirical perception without object or sign from the pure and empty property of our external and internal mind is the Archimedean fulcrum 'give me to stand' and 'origin of the deception', the cornerstone of critical idealism and its tower-and lodgebuilding of pure reason. The given or taken materials belong to the categoric and idealistic forests, peripatetic and academic store rooms. The analysis is nothing more than a cut according to the fashion, as the synthesis is just an artful seam of a good leather- or clothes tailor. For the sake of the weak reader, I have interpreted that which the transcendental philosophy metagrabolises (sounds out at length) to the sacrament of language, the letters of its elements, the spirit of its institution. I leave everyone to unfold the closed fist into an open hand. ${ }^{1}$ (Hamman 1825 [1784]:16, [author's own translation])

This passage, as with most of Hamann's writing, needs interpretation - the closed fist needs to be expounded into an opened hand.

In his Critique of pure reason, Kant (1855 [1781]:31-43) attempts to demonstrate - with clarity and not hypothetically, but with apodictic certainty - that the true basis of thought lies in the universal conditions of perception which exist in all humans before the diverse vagaries of experience can arise: the categories of space, time, number and causality being the chief of these. In his response, Hamann (1825 [1784]:6) denies the possibility of universal reason, free from the vagaries of tradition and experience, as reason always depends on language and all language arises out of experience handed on, as sensus communis, in the process of tradition. Hamann (1825 [1784]:8) denies that a perfect, well-defined, abstract language without reference to everyday language is possible, calling this an ens rationis [pure thought] 'nothing'. Consequently, he decries the whole project of universal and controlling reason of an isolated individual, which Kant (1855 [1781]:17) proposes, as ill-conceived (Hamann 1825 [1784]:9).

Instead, Hamann (1825 [1784]:9) starts with the insight that all thought is language and therefore participates in the particularity of experience and language. Universals are just particular concepts, arising out of particular experiences, which have been given very extensive fields of meaning. However, in language, the material - the sound of a syllable, the shape of a letter, of a word, becomes a carrier of meaning (Hamann 1825 [1784]:12). Hamann sees this joining of the material basis to the content of meaning as fundamentally analogous to that of the sacrament - where the meaning of the word of grace is joined to the material symbol of bread, wine or water. Hamann (1825 [1784]:16) suggests that the key to overcoming the matter-spirit dualism lies in the 'sacrament of language'. Before we explore the consequences of such an approach, let us see whether there is evidence that would support this claim.

\section{Language, mind and evolution}

This question brings us to Darwin and the theory of evolution. Whilst the general philosophical approach in Darwin's time still presupposed spirit-matter dualism, the theory of the evolution of humans presupposes a continuum between matter and spirit. It suggests that the human mind and spirit arose in a continuous process. At some stage, the beings that evolved from early apes, and later were our ancestors, began

1.The German orginal is as follows: Diese letzte Möglichkeit, die Form einer empirischen Anschauung ohne Gegenstand noch Zeichen aus der reinen und leeren Eigenschaft unseres äußern und innern Gemüths herauszuschöpfen, ist eben das $\Delta \circ \varsigma \mu$ ol $\pi \varepsilon \zeta \omega$ und $\pi \rho \omega \tau \omega \psi(\psi \varepsilon \cup \delta$ oc, der ganze Eckstein des kritischen Idealismus $\Delta$ und $\mu$ seines Thurm- und $\pi \varepsilon{ }^{\prime}$ und seines Thurm- und Logenbaues der reinen Vernunft. Die gegebenen oder genommenen Materialien gehören den kategorischen und idealischen Wäldern, peripatetischen und akademischen Vorrathskammern, Die Analyse ist nichts meh als jeder Zuschnitt nach der Mode, wie die Synthese, die Kunstnath eines zünftigen Leder- oder Zeugschneiders. Was die Transcendental=Philosophie metagrabolisirt, habe ich, um der schwachen Leser willen, auf das Sakrament der Sprache, den Buchstaben ihrer Elemente, den Geist ihrer Einsetzung gedeutet, und überlasse es einem jeden, die geballte Faust in eine Flache Hand zu entfalten. 
cognition and became human - as the name Homo sapiens implies. When did this occur? And what change made them human, cognitive, inspirited beings? What in matter can give rise to spirit? Indeed, the opposition to the suggestion of continuity between matter and spirit, between animal bodies and human minds, was one of the main reasons for contemporaries of Darwin to reject his theory (Peacocke 1985:101-102).

In human palaeontology, tool manufacture had often been used as the indicator of humanness because it implies planning and self-awareness. This approach corresponds to Kant's interpretation of what human spirit, human mind, is - a theoretical mind capable of accurately and objectively perceiving objects and a practical mind capable of manipulating objects to its will, capable of intention and planning (Kant 1855 [1781]:464). This corresponds to the definition of human beings common to much of philosophical discourse - a rational being with free will. The fundamental nature of the human being perceived in this approach corresponds to the names given to human ancestors: Homo habilis and Homo ergaster (Wood \& Collard 1999:197).

However, recent research in palaeoanthropology indicates that tool use, and even tool construction, is an insufficient criterion for humanness. Studies indicate that crows and apes can also modify objects to serve as tools. Also, the development of artefacts, cultural settlements and complex behaviour suddenly increased in speed approximately fifty thousand years ago - indicating a qualitative shift from biological adaptation to cultural adaptation and cultural transmission of information. This is now taken as the true indication of the origin of humans as we experience ourselves. It is linked to the appearance of complex, grammatical language, associated with the Broca's area of the brain (Cela-Conde \& Marty 1998:448; Diamond 1992:141). Religious behaviour originates at the same time, indicated by burial rituals and cultural construction, by the decoration of artefacts and production of paintings, as well as the construction of musical instruments (Ambrose 2001:1749; Cross, Zubrow \& Cowan 2002:28; Mcbrearty \& Brooks 2000:458;). Therefore, although it is more difficult to detect than tool construction, language use arguably is the defining characteristic of being human, much more so than tool use or construction, which does not seem to denote an equally dramatic shift from pre-human hominids. Spirit seems therefore to be linked to language, in terms of the evolutionary origin of human beings.

One intriguing fact in human evolution is the extraordinary capacity, complexity and information processing ability of the human mind. The brain evolved in a hunter-gatherer society, where the information-processing needs of the average member were vastly less than those required of humans in our post-industrial information society. The brain has not changed dramatically in structure since then. The same brain that today can devise sub-quantum physical theories, process thousands of pages or screens of information, then only needed to do a little more than the average baboon still does today - gather tubers and insects. The ability to devise theories that span the evolution of the universe, that can project back 15 billion years and forward as equally long, and construct devices and societies as complex as supercomputers and mega-cities, seems to outweigh by far the evolutionary needs of the hunter-gatherers in which this mind evolved. Added to this is the significant evolutionary cost of a large brain: the problem of giving early birth to large-sculled children, caring for them in a long infancy, and the fact that the brain consumes an inordinate proportion of the energy of the body: $20 \%-30 \%$. The one parallel in other species of an organ that rapidly develops in size and complexity beyond the direct needs of survival is those that show sexual competence and health (Miller 2000:130-132). Some examples of this are the tails and crests of wydahs, paradise birds and peacocks, as well as the antlers of elk. The hypothesis therefore is that brain size and function evolved to demonstrate health and ability as a preferential partner in mate selection. Yet how was this brain size demonstrated? Rapid growth in brain size occurred directly after the formation of language areas and so it therefore stands to reason that brain size was demonstrated through linguistic ability in the mate-selection process. The implication is that we developed our mind in order to compose love songs, not in order to make tools. ${ }^{2}$

The second linkage of matter and spirit, according to science, originates in the area of complexity. Instead of asking how our humanness arose historically in the process of evolution, the question here is how does our humanness actually arise out of the way we are made? How does the mind that I am arise out of the body that I am, too? Whilst the interaction of mind and body had, in the history of philosophy, been linked to the pineal gland or explained in terms of pre-stabilised harmonies of monads, the attempt of modern neuroscience to answer this question lies in the theory of complex, non-linear systems. The theory of complex systems indicates that these systems develop a mode of behaviour wherein the system behaves as a whole and its behaviour must be studied on the level of the system as a whole, using different categories from the study of the parts of the system (Clayton 2006:677, 681; Peacocke 1986:28-29, 90-91, 1993:224-225, 2000:135). This mode of behaviour is also called supervenience or emergence. A typical feature of this is that the higher level reality - the meaning - can be instantiated in different ways in the lower level - the representation - and that the representation level, whilst constrained by lower-level laws, is flexible enough to take different configurations that are of equal energy, but carry different meaning. There is no effective difference between different arrangements of the bases in a DNA string, but the different arrangements carry different information. This is therefore similar to the relationship between the physical representation of words in sounds or written signs and the meaning of those signs in a certain language-context (Murphy 1998:476-477).

2.This theory was developed in a somewhat light-hearted conversation with my wife over coffee, and later verified in consulting the literature - Hamann (1822 [1760]:258) supposed something similar. 


\section{Humanity and language, rationality and relationality}

If, then, it can be reasonably held that the humanity of human beings lies in their ability to use language in pursuit of relationships, and not primarily in their ability to grasp the world rationally nor in their ability to manipulate the world technically, what then would be the consequences for the conception of humanity? This conception would define humans not purely as rational beings, but rather as relational beings, thus coming closer to the African understanding of muntu ngumuntu ngabantu. ${ }^{3}$ Language is not something that can be used purely to describe the world (Miller 2000:359), something purely theoretical and interpreted in the mode of seeing as the primary sense, but rather something relational, with hearing - and answering - being the fundamental sense and mode of perception. The implication is that the human is not a distant and unrelated observer, nor a controlling artificer, but a communicant, a partner and participator in a communicative process (Hamann 1822 [1760]:261).

Following this, human self-understanding would shift by necessity and the source of self-worth would have to be redefined. I am more human not when I know more, nor when I have more power, but when I relate more and deeper through the language I use. This would especially be true if these relationships are truly relationships of communication and not relationships of power exercise for in such relationships, both parties would be, and would make themselves, vulnerable to one another and, through these relationships, a community would be created where the search for the common good would outweigh the competition for position. In our broken world, this may be a simplistic expectation - and real relationships, in our experience, most often contain struggles for power and recognition; however, a tendency towards humans being viewed more relationally and less in terms of abilities may be indicated by this perspective.

If this would be accepted as basis of society, then our society would spend less effort on controlling reality and exploiting it for knowledge or goods or power and more on the development of relationships. Even knowledge would be conceived of differently - for the ideal of knowledge in the age of science is that originating from Francis Bacon (1825:219), who defined knowledge in terms that related it to technical mastery over the world: knowledge is power. Knowledge based on a fundamentally relationally conceived language would be closer to the Hebrew understanding of

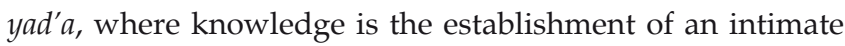
and understanding relationship between knower and known. I believe this shift would result in a more respectful approach to our world, which could result in a healthier relation to our environment - which would then lead to a better chance of our survival on this planet.

3.This common African expression can be translated as: 'A human being is human through other humans.'

\section{Relationality, language and God's Spirit}

Furthermore, if that which makes us truly human is the image of God in us, and our spirit is an echo of the Spirit of God, then our concept of God would shift as well. Whilst humans who conceptualise their humanity fundamentally as their ability to discern or master over other creatures would define God in terms of mastery over creation, those who would understand themselves fundamentally as relational beings would conceive of God rather as one who is deeply relational. The classical theistic definition of God - in terms of omnipotence and omniscience - defines God in terms of power - and is rightly criticised by Feuerbach (1981:262). The conception of God in terms of relations corresponds better, in my view, to the God of Jesus of Nazareth, whose main interest is the establishment of relationships with us and who is, as Trinity, fundamentally relational. Of course, part of entering into a relationship is becoming vulnerable - contrary to the detached observer or the master, who is invulnerable. The vulnerability of God, God's pain at broken relationships, can clearly be seen in the biblical witness, from Hosea to Jesus (Fretheim 1984:155; Moltmann 1972:261).

This understanding of God also has consequences for our fundamental approach to the world. In the 18th and 19th centuries, an age where God was conceived of as Master and designer, the world was conceived of as subject and machine, subjected to absolute and unchanging laws (Barrett 2000:58). However, if God's Spirit that penetrates and underlies the created order is conceived of in terms of language, then the world, too, will be interpreted in the metaphor of language and relationship. The laws of this world will be conceptualised as being akin to the laws of grammar and good style, rather than as the absolute laws of an absolute monarch. The laws of grammar underlie the possibility of expressing meaning in language - but they are, in their particular shape, neither necessary, nor is obedience to them absolutely mandatory - for whilst wholesale disregard for the rules of grammar destroys meaningful communication, the rules of grammar and style can be bent or broken occasionally with poetic license, when it serves the communication of meaning by an artful author (Hamann 1821 [1758]:138, 1822 [1759a]:17, 1821 [1759b]:508). In this conception, attention is focused away from an exclusive concern with the laws and onto an attempt to understand the meaning of the writing. A world seen only in terms of absolute laws has no meaning - but a world in which the laws of grammar undergird the communication of a particular text can have deep and profound meaning in its overall development, for each of its parts can contribute to that meaning.

Does such a description fit our understanding of the world? The sciences of complexity indicate that it does, that the laws of this world are precisely such as to allow construction of intricate patterns that are not predetermined by the laws, but can develop because of the stability and freedom these laws provide. This balance between freedom and structure is sometimes referred to as the edge of chaos (Gutowitz \& Langton 1995:52; Miller \& Scott 2007:129). 
Can we understand this meaning? Can we read the language of the world? To understand a language, one needs a key, a Rosetta stone. For, in language, individual patterns or words do not have intrinsic meaning - rather, their meaning is fixed by usage. There is nothing in the letters 'wand' that predestines one to interpret them as a side of a room, in German, or as a magic stick, in English. Meaning is a priori arbitrary, but a posteriori necessary. What can be the Rosetta stone for understanding the meaning of history? Hamann answers that it is revelation, specifically the revelation of God in Christ that allows us to find the key to the language of history (Hamann 1821 [1758]:148, 1822 [1760]:263). The difference, then, between a believer and an unbeliever in the interpretation of the world is simply that between someone who has had access to the key to learn to understand the language and one who has not.

\section{Language as sacrament}

But why call language a sacrament? Hamann (1825 [1784]:16) does so in reference to the definition of a sacrament that underlies the Lutheran understanding and is often quoted in Lutheran writings: 'accedat verbum ad elementum et fit sacramentum' (Luther 2000 [1530]:468). ${ }^{4}$ When the word, or more properly, the meaning, is joined to the element, the sacrament results. In this perspective, a sacrament has three constituent aspects: a material sign, a meaning that is attached to this, which relates subsequently to the gospel of the gracious self-communication of God. These three elements can be seen in language. Indeed, is language not a prime example of the joining of meaning to a material entity; that is, an auditory signal or a written sign? And is language, after all we have said, not a sign of the gracious communication of God, who desires relationship and has given himself to us in a world that is suited for, and geared toward, the establishment of relationships? Therefore, does language, by its very existence, not give us an indication of the meaning of the world - a continuous growth in complexity and in the depth and extent of relationships amongst the beings in it?

If language can be regarded as indicative of the communication of God with us - in the world, in the word and in the central sacrament of the incarnation of Christ - then language itself participates in the sacramental nature of the word, the word that was in the beginning, was God, and yet became flesh. It is the nearness of language to this incarnated Word that gives it sacramental character. In this sacramental character, we see both God's self-communication as the ultimate source of language - for God created the world such that it has the character of language, so that he may communicate through it and with it - and God's intention of establishing communication embodied in relationships within God's creation. It is in such a relationship, in such a communication, that the dichotomy of matter and spirit is overcome. The consequences of this approach have been indicated in the development of this argument: if the meaning of the world is seen in language, then relationships of communication - and self-communication - become essentially important, rather than those of abstraction or manipulation. Such an approach can contribute to a healing of the divisions engendered by the modern dualisms.

4.That is, 'The word joins the element and makes the sacrament.'

\section{Acknowledgements Competing interest}

The author declares that he has no financial or personal relationship(s) which may have inappropriately influenced him in writing this article.

\section{References}

Ambrose, S.H., 2001, 'Paleolithic technology and human evolution', Science 291(5509), 1748-1753. http://dx.doi.org/10.1126/science.1059487, PMid:11249821

Bacon, F., 1825, The works of Francis Bacon, Lord Chancellor of England: A new edition, vol. 1, ed. B. Montague, Esq., William Pickering, London.

Barrett, P., 2000, Science and Theology since Copernicus: The search for understanding, University of South Africa, Pretoria.

Calvin, J., 1843, Institutes of the Christian religion, vol. 1, transl. J. Allen, Presbyterian Board of Publication, Philadelphia, PA.

Carrier, M. \& Mittelstrass, J., 1995, Mind, brain, behavior: The mind-body problem and the philosophy of psychology, Walter de Gruyter, Berlin.

Cela-Conde, C. \& Marty, G., 1998, 'Beyond biological evolution: Mind, morals and culture', in R.J. Russell, W.R. Stoeger \& F.J. Ayala (eds.), Evolutionary and molecular biology: Scientific perspectives on divine action, pp. 445-451, Vatican Observatory, Rome.

Clayton, P., 2006, 'Emergence from physics to theology: A panoramic view', Zygon 41(3), 677-681. http://dx.doi.org/10.1111/j.1467-9744.2005.00768.x

Cross, I., Zubrow, E. \& Cowan, F., 2002, 'Musical behaviours and the archaeological record: A preliminary study', in J. Mathieu (ed.), Experimental Archaeology: British archaeological reports international, ser. 1035, pp. 25-34, Archaeopress, Oxford.

Diamond, J., 1992, The third chimpanzee: The evolution and future of the human animal, Harper Perennial, New York, NY.

Feuerbach, L., 1981, Gesammelte Werke, vol. IV, ed. W. Schuffenhauer, AkademieVerlag, Berlin.

Fretheim, T., 1984, The suffering of God, Fortress, Philadelphia, PA.

Gutowitz, H. \& Langton, C., 1995, 'Mean field theory of the edge of chaos', in F. Morán (ed.), Advances in artificial life: Third European conference on artificial life proceedings, Granada, Spain, June 04-06, 1995, pp. 52-64, Springer, Berlin.

Hamann, J.G., 1821 [1758], 'Brocken', in Hamann's Schriften, vol. I, ed. F. Roth, pp. $125-148$, G. Reimer, Berlin

Hamann, J.G., 1822 [1759a], 'Sokratische Denkwürdigkeiten', in Hamann's Schriften, vol. II, ed. F. Roth, pp. 1-50, G. Reimer, Berlin.

Hamann, J.G., 1821 [1759b], 'To Kant, 30 Okt 1759', in Hamann's Schriften, vol. I, ed. F. Roth, pp. 508-509, G. Reimer, Berlin.

Hamann, J.G., 1822 [1760], 'Aesthetica in nuce', in Hamann's Schriften, vol. II, ed. F. Roth, pp. 255-308, G. Reimer, Berlin.

Hamann, J.G., 1825 [1784], 'Metakritik über den Purismum der reinen Vernunft', in Hamann's Schriften, vol. VII, ed. F. Roth, pp. 1-15, G. Reimer, Berlin.

Kant, I., 1855 [1781], Critique of pure reason, transl. J.M.D Meiklejohn, Henry G. Bohn, London.

Kant, I., 1976 [1788], Critique of practical reason and other writings in moral philosophy, transl. L.W. Beck, University of Chicago Press, Chicago, IL.

Laurikainen, K.V., 1991, 'Causality and quantum mechanics', Foundations of Physics Letters 4(2), 197-201. http://dx.doi.org/10.1007/BF00666053

Luther, M., 2000 [1530], 'The large Catechism', in R. Kolb \& T.J. Wengert (eds.), The Book of Concord: The confessions of the Evangelical Lutheran Church, pp. 377-480, Fortress, Minneapolis, MN.

Mcbrearty, S. \& Brooks, A.S., 2000, 'The revolution that wasn't: A new interpretation of the origin of modern human behavior', Journal of Human Evolution 39(5), 453563. http://dx.doi.org/10.1006/jhev.2000.0435, PMid:11102266

Miller, G., 2000, The mating mind: How sexual choice shaped the evolution of human nature, Heinemann, London.

Miller, J.H. \& Scott E.P., 2007, Complex adaptive systems: An introduction to computational models of social life, Princeton University Press, New York, NY.

Moltmann, J., 1972, Der gekreuzigte Gott, Kaiser, Munich.

Murphy, N.,1998, 'Supervenience', in R.J. Russell, W.R. Stoeger \& F.J. Ayala (eds.) Evolutionary and molecular biology: Scientific perspectives on divine action, $\mathrm{pp}$ 474-478, Vatican Observatory, Rome.

Peacocke, A., 1985, 'Biological evolution and Christian theology - Yesterday and today', in J. Durant (ed.), Darwinism and divinity, pp. 101-130, Blackwell, Oxford.

Peacocke, A., 1986, God and the new biology, JM Dent \& Sons, London.

Peacocke, A., 1993, Theology for a scientific age, SCM Press, London.

Peacocke, A., 2000, 'Chance and law', in R.J. Russell, N. Murphy \& A.R. Peacocke (eds.), Chaos and complexity: Scientific perspectives on divine action, pp. 123-146, Vatican Observatory, Rome.

Shimony, A., 2001, 'The reality of the quantum world', in R.J. Russell, P. Clayton, K. Wegter-McNelly \& J. Polkinghorne (eds.), Quantum mechanics: Scientific perspectives on divine action, pp. 3-16, Vatican Observatory, Rome.

Smith, A., 1843 [1776], An inquiry into the nature and causes of the wealth of nations, viewed 18 June 2009, from http://www.adamsmith.org/smith/won-index.htm

Wood, B. \& Collard, M., 1999, 'The changing face of Genus Homo', Evolutionary Anthropology 8(6), 195-207. http://dx.doi.org/10.1002/(SICI)1520-6505(1999) 8:6<195::AID-EVAN1>3.0.CO;2-2 